\title{
The Impact of Regulatory and Supervisory Structures on Bank Risk and Efficiency: Evidence from Dual Banking System
}

\author{
Nafis Alam \\ Assistant Professor, Nottingham University Business School, \\ The University of Nottingham Malaysia Campus \\ E-mail: nafis.alam@nottingham.edu.my
}

\author{
Received: March 13, 2012 Accepted: April 5, $2012 \quad$ Published: June 1, 2012 \\ doi:10.5296/ajfa.v4i1.1507 URL: http://dx.doi.org/10.5296/ajfa.v4i1.1507
}

\begin{abstract}
James Madison once said "If men were angels, no government would be necessary". Madison's view has direct implications for efficient bank supervisory and strong regulatory strategies. On the onset of 2007-08 subprime crisis banking system across the globe were left exposed to financial tsunami due to over-expansion and excessive risk concentrations. This incident should provide regulators wake up call to further develop and strengthen the regulatory system with new and strict monitoring mechanism. In the given context, this paper will investigates the linkages between bank regulatory and supervisory structures associated with Basel III's pillars and various aspects of banks' efficiency and risk. The analysis will be focussed on dual banking system over the period 2006-2010. Our results suggest that regulations and strict monitoring of banking operation, and higher supervisory power of the authorities, increase the technical efficiency for Islamic banks but decreases convention banks efficiency. We observe the opposite effect in the case of restrictions on bank activities, with higher restrictions having a reduction in risk taking of Islamic banks while increasing the risk taking of conventional banks. Results also indicate that Islamic banks are better prepared towards the implementation of Basel III guidelines compared to their conventional counterparts.
\end{abstract}

Keywords: Dual banking, Banking Regulation, Bank performance, Bank Risk

JEL classification: G15, G21, G28, C14 


\section{Introduction}

The banking system around the globe has been in recent years going through some of the most intense criticism and scrutiny. In part many believe the lack of regulations and supervisory structures have brought the world to a brink of financial collapse, while on the opposite side of that coin many believed the years of prosperity the world had experienced just prior to the collapse were largely in part due to the deregulation or lack of regulation hence a near free market with regard to the financial sector (Reinhart and Rogoff. 2008; Brunnermeier \& Pederson, 2009). Could there possibly be better efficiency and possibly profitability where a properly implemented regulatory and supervisory framework is in place? Would evidence suggest so? This paper will try to resolve some of the myth by providing empirical support.

Banking regulations can generally be defined as the frameworks controlling the creation, operation and liquidation of banks in an economy. These regulations are put in place by Central Banks and finance ministries and the control is exerted usually through monitoring carried out by specialized banking supervisory authorities. Spong (2000) from the Federal Reserve Bank of Kansas City highlights a few important reasons for introducing bank regulations. The most basic reason for introducing regulations is to protect depositors from undue risks to their deposits. Businesses and individuals alike hold significant portions of their funds in banks and there are valid concerns from them with regards to protection of their funds. As a result, authorities respond to such concerns with regulations attempting to protect the bank depositors.

Meanwhile, with enormous amounts of transactions conducted daily by businesses and individuals, a stable framework is required to ensure smooth and acceptable methods of the payments system are in place in an economy. Bank regulations try to provide this stable framework which seeks to assure certainty and safety to users of the banking payment system which is critical for the wellbeing of the economy. Moreover, apart from maintaining public confidence, banking regulations also try to create a regulatory environment where banks are expected to be efficient and competitive; and are also expected to provide reasonable levels of banking services throughout the economy.

The traditional view of the impact of bank regulation is that higher capital requirements will have a positive effect on the banking sector. However, some studies indicate that capital requirements increase banks' risk-taking behaviour (e.g. Blum, 1999; Calem and Rob, 1999). Barth et al. (2004) find that while stringent capital requirements are associated with fewer non-performing loans, capital stringency is not robustly linked with banking sector stability, development or bank performance (measured with overhead and margin ratios) when controlling for other supervisory regulatory policies.

In theory, there tends to be support for both the official supervision approach and the private monitoring approach to bank supervision. The official supervision approach argues that official supervisors have the capabilities to avoid market failure by directly overseeing, regulating, and disciplining banks. By contrast, the private monitoring approach argues that powerful supervision might be related to corruption or other factors that impede bank 
operations, and regulations that promote private monitoring will result in better outcomes for the banking sector. If this would have been the case the world should not have witnessed global banking crises.

In another aspect of banking has been the recent rise of Islamic finance, while the rest of the world and industry continues on with the business of arguing as to what level of banking regulations is needed, there in many corners of the world is the rise of a different type of banking system, in this aspect it encompasses a wide array of concepts from fully fledged financial institutions to normal financial institutions having an Islamic financing arm that offers saving schemes, loans or bonds commonly known as Sukuk.

However like every system that is theological based it is often open for interpretation and often it is done nationally or regionally, the Islamic Finance industry has also been riddled with many of such issues many of which could boil down towards lack of proper supervision and many is simply due to the lack of compliance and regulatory measures. When reading such a paper it is easy to dismiss the importance of Islamic Banking whether because it is through our own ignorance, lack of understanding to the system, prejudices and to a certain extent familiarity with conventional banking. However Islamic Financial Markets are among the fastest growing financial products in the world. This will see further growth in years to come as more and more countries are embarking on Islamic banking and discovering the benefits of using Islamic Finance over conventional financing schemes. As highlighted by Perry \& Rehman (2011) "while many of the conventional banks suffered major loses in the aftermath of the sub-prime mortgage crisis, most banks following the Islamic system were largely profitable". However there exist some dark clouds over the horizon for it to be accepted universally as a mainstream bank but mostly as an alternative.

Thus one of the major contributions of this paper is to empirically verify the role of regulatory and supervisory structure on the efficiency and risk taking for both conventional banks and Islamic banks under dual banking system. For the best of the knowledge of author this will be first quantitative study to highlight the banks' risk and return in dual banking system. Another motivation for this study is to substantiate if the efficiency and risk taking for Islamic banks and conventional banks varies under given regulatory and supervisory structures.

The new regulation underlining Basel III aspires to make the global banking system safer by redressing many of the flaws that became visible in the recent financial crisis. Improving the quality and depth of capital and renewing the focus on liquidity management is intended to spur banks to improve their underlying risk-management capabilities. This will raise the biggest challenge for banks, without compromising with the returns they need to incorporate higher level of risk management tools. With the onset of Basel III regulations it is imperative to know which banking system Islamic or conventional are better equipped to withstand any future financial turmoil.

Existing literature on regulation and supervision linkage with banks' risk and efficiency is limited and purely focusses on individual countries, single banking system or simple accounting ratios. (Barth et al., 2003 a,b; Demirguc-Kunt, et al., 2004 Barth et al., 2004; Beck 
et al., 2006; Berger et al., 2008). This paper will be step forward and contribute two fold to the existing literature by first investigating the impact of bank regulatory and supervisory structure on both conventional and Islamic banks' efficiency as well as on their risk. Secondly this paper will also assess the readiness of dual banking system towards the implementation of Basel III. The chosen period of analysis is 2006-2010 for eleven major dual banking systems (Egypt, Bahrain, Bangladesh, Indonesia, Kuwait, Malaysia, Pakistan, Qatar, Saudi Arabia, Turkey, and UAE).

Overall our results show that that regulation and supervision are positively related for conventional bank technical inefficiency and negatively related for Islamic bank technical inefficiency. In case of impact of regulatory and supervisory practices on bank risk taking we did not find any major differences between the two types of bank.

The rest of this paper is organized as follows: section 2 includes a literature review while section 3 presents the methodology, variables and data. The empirical results are explained in sections 4 and section 5 concludes the paper.

\section{Literature Review}

If we focus on regulation literature the declaration here is that most if not all the literature whether calling for more or less regulation will be applicable to the financial services industry regardless of whether it is conventional or Islamic. It is hoped that after this paper is written there would be better research into regulations that would be specifically for dual banking, especially so if there is relevance that special regulatory and supervisory framework is required.

One of the biggest critique and vocal in regard to the issue of bank regulations are Barth, Caprio and Levine. Barth, Caprio and Levine, (2008) noted that most countries with a functioning financial system had made significant changes to their bank regulatory framework, this is especially so in many developing and Asian countries after the East Asian Financial Crisis of the late 1990s. They do not appear to submit that it might be for the better since mostly it has been about following the Basel guidelines, strengthening capital requirements and the empowerment of supervisory bodies. The criticism by these authors is there is little evidence to suggest the implementation of these measures lead to a major improvement of the banking system in regard to their efficiency, stability and corruption. Another aspect criticized were the implementation of private monitoring though consistent with the third pillar of Basel II, it does not appear that these have brought about as much an effect as hoped for by policy makers. It was further argued that where banks introduced forced to curtail their non-lending activities then this brought forth further issues in regards to their profitability and to an extent their efficacy. Often many regulations tend to be knee-jerk reactionary measures at time of crisis it is claimed, this isn't farfetched from the truth as it is indeed being seen to a large extent till today. They pointed out that in Malaysia's case upon the East Asian crisis most banks had to cease with the vast majority of their non-lending activities; however where it appears to come off as a bad policy, the vast majority of Malaysian banks emerged from the more recent crisis in a far stronger position than many blue-chip banks in USA. 
In the subject of bank regulations, there is also evidence in regard to the microeconomics aspect to it. According to Barth, Caprio \& Levine (2007) data shows little evidence that a strengthened ability of supervisory framework in regard to monitoring and discipline of banks have an impact in improving bank efficiency or even banking and the commercial sector relationships. However there is a positive effect with regard to increased supervision and corruption in the banking sector. Again there was a call that a private monitoring of banks had a better effect in regard to their efficiency. Where corruption is a major issue in the banking industry, the academicians were of opinion that proper disclosure could bring forth better banking efficiency on condition that the legal system was a fully developed and strong one.

In their earlier paper, (Barth, Caprio, Levine, 2004) using data from 107 countries in regard to their supervisory and regulatory scope they examined the relationship between this and how it affects development in the sector, fragility and efficiency. It thoroughly examines issues in regard to restrictions on banking activities, barriers to entry especially in regard to foreign banks, capital requirements, deposit insurance, powers of the supervisory body together with its resources and independence, stringency of loan classification including guidelines to this regard, disclosures and finally to the extent in which government ownership influences the banking sector.

When it came to the issue of state ownership of banks, there has always been negativity towards this concept especially in many developed countries. It was pointed out by their findings that there was again no evidence to suggest that ownership by state had any positive effects on efficiency and on the contrary it also showed more corruption and poor development in the financial services industry. They submitted that a better way forward for the development of a proper banking and financial industry was to have forced disclosures of accurate information, privatization of banks and for there to be incentives for corporate control of the banks. It should however be noted that this paper was written prior to the financial crisis and it is quite unlikely that governments would be willing to have a completely unregulated financial services industry as seen in the previous decade.

Often, when dealing with the issue of Islamic banking, a very red flag is often raised that many of these products come from countries where there are greater rates of corruption or in some cases a weak legal system, Beck et al. (2006) examines the relationship on the need of bank supervision with regard to corruption and lending. According to their paper, the main research question was "Which commercial bank supervisory policies ease or intensify the degree to which bank corruption is an obstacle to firms raising external finance?" Their findings were again fairly consistent with available literature. They submitted 3 main conclusions. Firstly evidence shows that a powerful supervisory agency with broad powers does not better regulate or facilities efficient corporate finance. The evidence suggests that in countries with greater supervisory powers especially with regard to intervening, the data suggest that there would be more likelihood of corruption with these than in places without such supervisory or regulatory agencies. Secondly, a regulatory and supervisory framework that allows for interventionism tends to be a tool for politicians to manipulate, it often brings forth evidence that where such a system is in place, it also brings poor state governance. 


\section{Mll Macrothink}

Asian Journal of Finance \& Accounting

ISSN 1946-052X

2012, Vol. 4, No. 1

Thirdly, their analyses are consistent that private monitoring is a better solution. This is especially so with greater information disclosures and without distortions in the market. Their data suggest that where private monitoring coupled with forced accurate information disclosure that there is an overall benefit to the integrity of the financial system of a nation and this will only work if there is already in place a good legal system. Politics aside, the authors were of opinion that supervision of financial institution clearly mattered, but the question to be asked is who the better ones to supervise are. Their results which are non-ideological suggest that better information and supervision are the best way forward in regard to reducing corruption in the banking sector especially with regard to lending. In hindsight, the authors could only have wished more of their suggestions were taken into account sooner with regard to bank regulations and supervision especially with the onset of the subprime crisis in the USA.

In a paper (Demirgüç-Kunt, Laeven \& Levine. 2004) that examined the impact of bank regulations, market structure and national institutions on the profitability of banks, the finding was that stricter barriers to entry and bank activities may increase cost of financial intermediation. The authors also presented evidence consistent with literature that regulations or stricter regulatory requirements did not bring about much benefit in regard to bank stability, it also impeded firms' ability to access financing from external sources. It also played a negative role in regard to the valuation of a bank. It also meant that overall development in the financial services industry would suffer a setback.

Literature in regard to bank diversification into non-traditional income sources also exist and also are of the tangent on whether regulation in this regard affects their efficiency. According to literature, (Laeven \& Levine, 2007) analysing dominant banking players in the industry and the impact of regulations, they attempted to show that diversified banks did not do as well as specialized ones, this is especially with regard to their investment funding and related activities.

Laeven \& Levine (2007) study is very much relevant to this paper as it is studying the effects on regulation and supervisory using evidence of a dual banking system. Generally it is accepted by the authors that diversification has a negative impact on bank performance, however instruments in which that could be put in place to overcome these impacts. Their findings were that firstly highly diversified banks performed much worse than those who had specializations. Secondly, it also depended on who the owners of such banks were, where it was state ownership then it had a very detrimental effect on performance but where it was a private enterprise regardless of domestic or foreign they were able to mitigate the negatives.

Often bank regulations are steeped in bureaucracy in regard to market entry. While it is often true that not everyone should be given a bank operating license just because they ask for one, it is generally accepted that in many countries where there are ease in regulations to market entry the dynamism of the financial sector improves by leaps and bounds. According to Casu \& Girardone (2006), a level playing field was the main objective for deregulation in the banking sector. The easing of entry somewhat made it easier for entry into the single market, but the main effects to it was a series of major consolidation. While their focus was more 
towards competition within the banking industry and its effects on efficiency and probability in the European Union many of the lessons from there could also be applied in regard to the analysis of the dual banking study this paper is on. Their findings further submitted that where the regulations attempted to make it easier for market entry it also brought about concentration and in all the European countries studied this was fairly consistent as deregulation brought on waves of consolidation and mergers between financial institutions. They concluded that "the relationship between competition and efficiency is not a straightforward one: increased competition has forced banks to become more efficient but increased efficiency is not resulting in more competitive EU banking systems."

It appears that more than one team of academicians are agreeable with regards to private monitoring of banks, hence it does not appear to be a largely American school of thought or one that is primarily propagated by American based institutions, even in Britain and Continental Europe there appears to be broad support for this issue. According to Delis, Molyneux \& Pasiouras (2009), there is an indication that regulations and incentives that promote private monitoring have a positive impact on productivity even where they utilized data and regression analysis that is different from the others. In their study of banks, Basel II, productivity and regulations, they concluded that there is an overall call by many international organizations and governmental bodies to implement a regulatory and supervisory framework that consist of stringent capital requirements, tighter supervisory controls and an empowered monitoring by the private sector there are little consensus in regard to which would work best, it is arguable that different countries may require different types of frameworks and there is no one size fits all system often pushed on by American academics or policy makers. It has been the case that only in recent years there have been more cross country studies and usually it is not significantly different in systems or wealth levels.

In a contrasting method of measuring efficiency of the banking system, Pasiouras, Tanna \& Zopounidis (2009) focussed on the role of regulatory and supervisory framework and their impact on banking efficiency utilizing a stochastic frontier analysis. Again it used a fairly large dataset with studies in 74 countries. Their main area of research was the effect of the regulations called upon by the three pillars of Basel II. Their findings point towards that cost efficient banks are not necessarily efficient in generating profits. Cost and profit efficiencies were significantly affected in a positive manner where there were requirements for disclosure of information, however the reverse was true where there were highly powerful supervisory frameworks in place, and hence the two are not mutually exclusive. Their submission in regard to regulating banks is in order for it to be done effectively then account needs to be taken among competition, efficiency and financial stability, this is especially so due to the effects that an improper and dysfunctional banking system could do to an economy of a nation as evidenced by the numerous financial crisis that occurred as a result in the $20^{\text {th }}$ century that as infrequent as they were the damage they did often eclipsed those of many natural disasters.

Overall the literature review can be summed up that most academicians submit that bank regulations and supervision does have an impact with regards to bank efficiency and risk 
taking. Much of the literature has also called on policy makers to maintain deregulations and allow banks to self-regulate themselves. It is a difficult to evaluate whether much of the academicians submit that due to conviction of the free market system or is it genuinely the case. Often these academics come from countries where there are legal systems that could be considered to be among the most advanced in the world and had general high standards of rule of law. However, the literature submitted even where it is done comparatively it does submit that in most cases extra regulations will have an impact on the efficiency of a bank. The level of supervision in the financial services industry has a strong and adverse effect with regard to efficiency of a bank, this is especially so where the supervisory is a state supported establishment and has broad interventionist powers.

An aspect of regulations and supervision is where they come with restrictions. While evidence tend to point towards efficiency having a negative effect where a bank diversifies its financial type activities, it is often the case instead that where a restrictive banking system will in turn prevent the proper development of the financial services industry. This might be where a lot of developing countries may face hurdles and this research will try to empirically support this notion.

Thus it can be seen from the above discussion that there seems to be no study which focussed on regulation and supervisory impact on bank efficiency and risk taking in dual banking system and only handful of studies focussed on regulation impact on bank risk and return.

The next section outlines the details of the methodology and data used.

\section{Methodology}

\subsection{Efficiency Estimation}

The methodology employed by this paper is that of a frontier Data Envelopment Analysis (DEA) model. The DEA model of data analysis with regard to bank efficiency has generally been favoured by most academics (Berger et al., 1993; Berger \& Humphrey, 1997; Casu \& Molyneux, 2000). Despite criticism from some academics (Simar \& Wilson, 2011; Ramalho, Ramalho \& Henriques, 2010) it is generally accepted by most academics that the DEA model is a sound technique for efficiency estimation. McDonald (2009) examined the second stage DEA efficiency analyses and found that there are good arguments for treating DEA efficiency scores as descriptive measures in a second stage analyses. He summed it up that DEA method was simply the better one as it was relatively simple to use and a broad range of people could understand its usage and the idea behind it.

In the generic situation of $\mathrm{n}$ banks, with each of them consuming $\mathrm{m}$ different inputs to produce s different outputs and constant returns to scale, this translates into the following linear programming problem being solved $\mathrm{n}$ times; each time for a different bank in the sample: 


\section{Mll Macrothink}

$$
\begin{aligned}
& \operatorname{Min}_{\theta, \lambda} \theta, \\
& \text { st } \quad \theta x_{i}-X \lambda \geq 0, \\
& \\
& -y_{i}+Y \lambda \geq 0, \\
& \lambda \geq 0,
\end{aligned}
$$

where $\theta$ is a scalar, $\lambda$ is a vector of ones and finally $X$ and $Y$ are the $m \times n$ input and $s \times n$ output matrices respectively. In this context $\theta$ is the technical efficiency score of each bank and is measured relative to an estimate of the true production frontier which is known as the best practice frontier. When the value of $\theta$ is unity the bank operates on the efficient frontier and is therefore deemed efficient.

Data being pooled across 11 countries, selected on the basis that they are OIC member states and have an established dual banking system. An "intermediation" approach is being utilized as there is an assumption that all banks will have a certain amount of regulated framework and all will have to utilize capital, assets and some form of liabilities to function. According to Berger \& Humphrey (1997), this is the normal practice in vast majority of financial services industries. Accordingly, we consider personnel expenses, fixed assets and deposits plus short term funding as inputs and total amount in loan disbursement and total earning assets as outputs.

The estimated efficiency scores are then regressed against a set of regulatory, bank-specific and macro variables as explained in Section 3.2.

\subsection{Regulation and Bank Performance}

The modelling framework adopted to estimate the relationship between regulation, efficiency, and risk is built on from the approaches suggested by Pasiouras (2008), Kwan and Eisenbeis (1997), and Altunbas et.al (2007). We specify a system of equations and estimate these using Zellners's (1962) seemingly unrelated regression (SUR) approach. SUR will allow for simultaneity between banks' risk and efficiency with regulatory and supervisory structure while also controlling for other important environmental factors. It is believed that SUR can overcome contemporaneous cross-equation error correlation. There are two main motivations for use of SUR. The first one is to gain efficiency in estimation by combining information on different equations. The second motivation is to impose and test restrictions that involve parameters in different equations. The system of equations estimated is as follows:

$\mathrm{INEFF}_{\mathrm{ij}}=\alpha+\mathrm{bSPOWER}_{\mathrm{j}}+\mathrm{cCAPRQ_{j }}+\mathrm{dPRMONIT_{j }}+\mathrm{eACTRS_{j }}+\mathrm{fNLTA}_{\mathrm{ij}}+\mathrm{gTA}_{\mathrm{ij}}+$ $\mathrm{h} L A D_{\mathrm{ij}}$

$$
+\mathrm{i} L A T A C_{\mathrm{j}}+\mathrm{j} O E T A C_{\mathrm{j}}+\mathrm{k} L L P T A C_{\mathrm{j}}+1 \Delta G D P_{\mathrm{j}}+\mathrm{mLLR} R_{\mathrm{ij}}+\text { Year }_{\mathrm{j}}
$$

$$
\mathrm{LLR}_{\mathrm{ij}}=\alpha+\mathrm{bSPOWER_{j }}+\mathrm{cCAPRQ_{j }}+\mathrm{dPRMONIT_{j }}+\mathrm{eACTRS_{j }}+\mathrm{fNLTA}_{\mathrm{ij}}+\mathrm{gTA} A_{\mathrm{ij}}+\mathrm{h} L A D_{\mathrm{ij}}
$$


$+\mathrm{i} L A T A C_{\mathrm{j}}+\mathrm{jOETAC}_{\mathrm{j}}+\mathrm{k} L L P T A C_{\mathrm{j}}+1 \triangle G D P_{\mathrm{j}}+\mathrm{mINEFF}_{\mathrm{ijj}}+\mathrm{Year}_{\mathrm{j}}$

Definitions of all variables are provided in Appendix 1.

Equation 2 and 3 examine the impact of regulatory and supervisory structure on bank efficiency and risk taking behaviour. Individual bank inefficiency (INEFF) is the managerial technical inefficiency, which measures how far the bank is from the estimated efficient frontier (1- $\theta)$. It is obtained as the distance of a bank's observed technical efficiency from the estimated efficient frontier as explained in section 3.1. A number of bank-specific and country specific variables are also included that are believed to also explain the variation in bank risk and inefficiency across dual banking system. Loan loss reserves as a fraction to total assets (LLR) is used as measure of banking risk which is primarily used as measure of Tier 2 capital. The treatment of loan loss reserves as capital has received considerable attention in the wake of the financial crisis (Ng and Roychowdhury, 2011). Higher levels of reserves are suggestive of greater banking risk accounting for any future bad times. Of course, this estimation as measure of riskiness can be questionable and backward looking but accounting ratio like this has been widely used across literature to assess bank appetite for risk.

To account for Basel II and Basel III's pillars on bank regulation and supervision we use the data from Barth et.al (2001b, 2006, 2007b) World Bank database.

SPOWER is a measure of the power of the supervisory agencies. It is calculated on the basis of the answers to 14 questions indicating the extent to which supervisors can change the internal organizational structure of the bank and/or take specific disciplinary action against bank management and directors, shareholders, and bank auditors. Higher values of this variable indicate greater power of supervisory authorities to get involved in banking decisions. Strong official supervision may signal efficient banking institutions, preventing managers from engaging in excessive risk-taking behaviours.

CAPRQ is an index of capital requirements, accounting for both initial and overall capital stringency. The former indicates whether the sources of funds counted as regulatory capital can include assets other than cash or government securities and borrowed funds, as well as whether the regulatory or supervisory authorities verify these sources. The latter indicates whether risk elements and value losses are considered while calculating the regulatory capital. CAPRQ can take values between 0 and 8 with higher values indicating more stringent capital requirements.

PRMONIT is an indicator of private monitoring that takes values between 0 and 8 with higher values indicating higher disclosure requirements and more incentives to increase private monitoring. Barth et al. $(2006,2004 a)$ provide evidence that regulations that enhances and facilitates private monitoring can significant boost bank efficiency. More recently, Pasiouras (2008) shows that encouraging and facilitating private monitoring of banks can boost efficiency. 
ACTRS indicates the level of restrictions on banks' activities. It can take values between 0 and 4 with higher values indicating higher restrictions. It is determined by considering whether securities, insurance, real estate activities, and ownership of non-financial firms is unrestricted $(=1)$, permitted $(=2)$, restricted $(=3)$ or prohibited $(=4)$. We construct an overall index by calculating the average value over all four activities. According to Barth et al. (2001, 2003a,b), activity restrictions may have an important impact on bank efficiency by reducing competition and limiting economies of scope, which results in lower efficiency levels.

For the explanatory variables we used a broad range of variables that are believed to be important in explaining the performance and risk taking propensity of banks. The bank-specific variables include net loans to total assets (NLTA) as rapid loan growth may increase risk and impact adversely on bank efficiency in the long run. Banks that are more liquid may be more efficient in the sense that all other things being equal, an efficient bank can produce more output part of which includes liquid and other assets so we account for this by using liquid assets to deposits ratio (LAD). Bank size, through economies of scale, may influence the relationship between risk and efficiency so we control for the assets size of banks (TA). Big banks typically are more diversified and gain from other size advantages (Hughes et.al, 2001) so it is important to control for this factor. Generally, the effect of a growing size on efficiency has been proved to be positive to a certain extent (Athanasoglou et al., 2008; Fiordelisi and Molyneux, 2010).

Finally, a range of country-specific banking variables are included to take account of broad banking system differences across the nations. These include indicators of country banking system liquidity measured by banking system liquid assets to total assets in country (LATAC), efficiency measured by banking system operating expenses to total assets in country (OEPAC) and risk measured by banking system loan-loss provisions to total loans in country (LLPTAC). While these variables are similar to the bank-specific indicators they provide another aspect to the analysis in that they control for country differences in efficiency and risk. In other words they help to show if country-specific financial differences impact on bank-specific risk and efficiency. The average annual growth rate of per capita ( $\triangle$ GDP) is an environmental variable used to control for local economic conditions. A high level of per capita GDP captures the cyclical conditions of the macroeconomic environment. It is also expected to capture the implications for bank efficiency stemming from operating in different economic environment, as demand for financial products depends on the level of economic activity. Empirical studies tend to find that countries with relatively high GDP growth are characterised by more efficient banking institutions (e.g., Demirguc-Kunt and Maksimovic, 1998; Schure et al., 2004; Yildirim and Philippatos, 2007). Yearly dummy variables are included to control for time effects.

\subsection{Data}

The dataset used in this study is composed of conventional and Islamic banks from eleven countries (Egypt, Bahrain, Bangladesh, Indonesia, Kuwait, Malaysia, Pakistan, Qatar, Saudi Arabia, Turkey, and UAE) having a dual banking system. They are sourced either from data collected by BankScope database or done by manually referring to the annual reports of these 


\section{Macrothink}

Asian Journal of Finance \& Accounting

ISSN 1946-052X 2012, Vol. 4, No. 1

banks for year 2006-2010. The reasoning for a 5 year data test is because it would yield a better dataset due to accuracy and also where the Islamic banking system was newly established it would have had sufficient time to mature. The other reasoning to it is that it would also be able to monitor the overall performance during the recent financial crisis. 
Table 1. Sample description: number of banks and average asset size by country

\begin{tabular}{|c|c|c|c|c|c|c|c|}
\hline \multicolumn{8}{|c|}{ Islamic Banking (IB) } \\
\hline Country /Year & 2006 & 2007 & 2008 & 2009 & 2010 & Total by Country & $\begin{array}{l}\text { Avg. asset of all IB in } 2010 \\
\text { (Milln. USD) }\end{array}$ \\
\hline Bahrain (12)* & 13 & 15 & 17 & 17 & 17 & 79 & 2422 \\
\hline Bangladesh (15) & 3 & 3 & 3 & 3 & 3 & 15 & 709 \\
\hline Egypt (19) & 2 & 2 & 2 & 2 & 2 & 10 & 3854 \\
\hline Indonesia (5.5) & 3 & 3 & 4 & 4 & 4 & 18 & 1602 \\
\hline KSA (57) & 2 & 2 & 3 & 3 & 3 & 13 & 19897 \\
\hline Kuwait (35) & 3 & 3 & 3 & 3 & 3 & 15 & 17960 \\
\hline Malaysia (22.6) & 10 & 12 & 16 & 16 & 16 & 70 & 5121 \\
\hline Pakistan (6.4) & 5 & 6 & 6 & 6 & 6 & 29 & 555 \\
\hline Qatar (20) & 3 & 3 & 3 & 3 & 3 & 15 & 9668 \\
\hline Turkey (4.5) & 4 & 4 & 4 & 4 & 4 & 20 & 6480 \\
\hline UAE (18) & 7 & 7 & 9 & 9 & 9 & 41 & 8458 \\
\hline Total By Year & 55 & 60 & 70 & 70 & 70 & 320 & \\
\hline \multicolumn{8}{|c|}{$\begin{array}{l}\text { Conventional Banking } \\
\text { (CB) }\end{array}$} \\
\hline Country /Year & 2006 & 2007 & 2008 & 2009 & 2010 & Total by Country & $\begin{array}{c}\text { Avg. asset of all CB in } 2010 \\
\text { (Milln. USD) }\end{array}$ \\
\hline Bahrain & 9 & 9 & 9 & 9 & 9 & 45 & 10410 \\
\hline Bangladesh & 25 & 25 & 25 & 26 & 26 & 127 & 1815 \\
\hline Egypt & 12 & 12 & 12 & 12 & 12 & 60 & 9832 \\
\hline Indonesia & 34 & 35 & 36 & 36 & 36 & 178 & 6897 \\
\hline KSA & 8 & 8 & 8 & 8 & 8 & 40 & 31965 \\
\hline Kuwait & 6 & 6 & 6 & 6 & 6 & 30 & 18712 \\
\hline Malaysia & 13 & 13 & 13 & 13 & 13 & 65 & 35924 \\
\hline Pakistan & 16 & 16 & 16 & 16 & 16 & 80 & 4221 \\
\hline Qatar & 5 & 5 & 5 & 6 & 6 & 27 & 17369 \\
\hline Turkey & 21 & 21 & 21 & 21 & 21 & 105 & 21275 \\
\hline UAE & 11 & 12 & 12 & 12 & 12 & 59 & 24729 \\
\hline Total By Year & 160 & 162 & 163 & 165 & 165 & 816 & \\
\hline
\end{tabular}

Source: Bankscope database and Author calculation. ${ }^{*}$ Figure in parenthesis shows Islamic banking asset as percentage of total banking asset

\section{Empirical Results}




\section{Macrothink}

Asian Journal of Finance \& Accounting ISSN 1946-052X 2012, Vol. 4, No. 1

The banks' efficiency scores for both conventional and Islamic banking are estimated relative to a common best practice frontier by pooling the data across countries. This approach allows for estimating efficiency differentials not only between banks within a country but across countries as well using the same benchmark technology. 


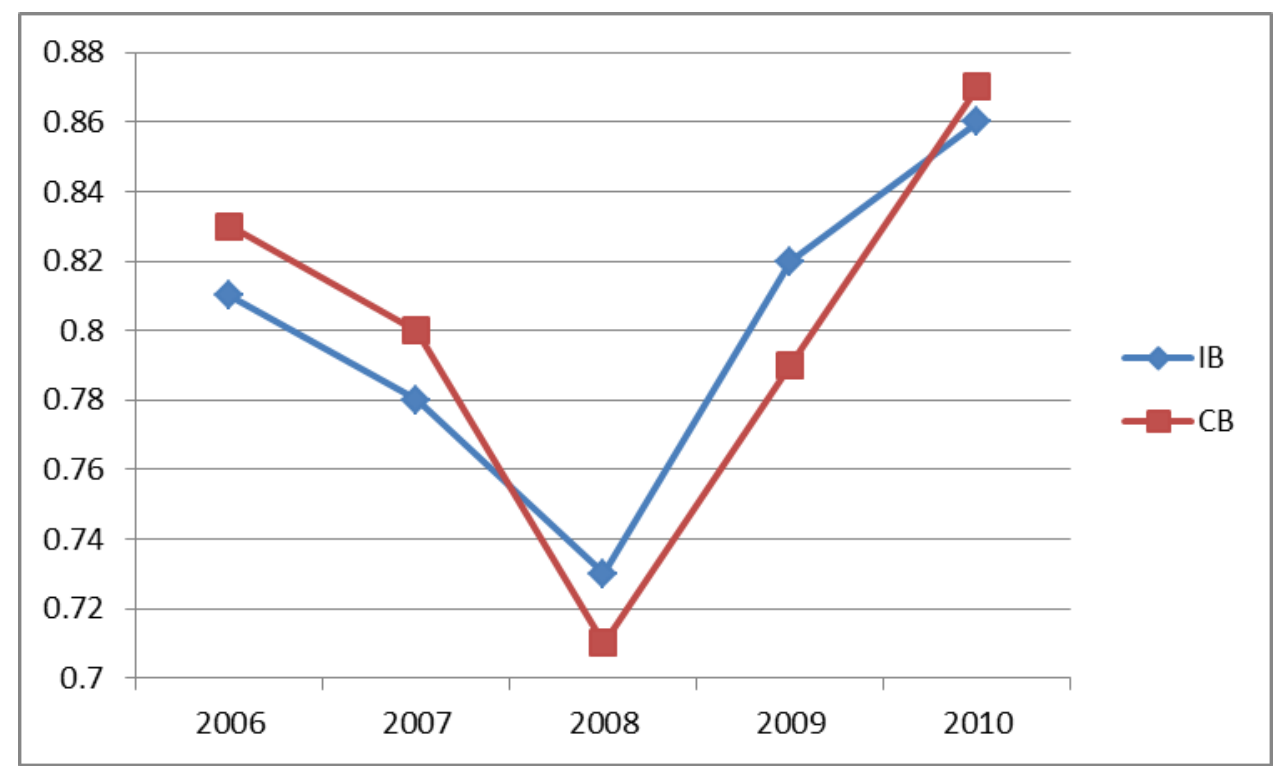

Figure 1. Technical Efficiency Scores by Year and Bank Type

Figure 1 (a) illustrates the average DEA efficiency scores by year and by bank type. Overall the result shows that on an average technical efficiency of conventional banks have outperformed Islamic banks efficiency except for year 2008 and 2009. This proves during the normal times conventional banks are able to achieve high level of technical efficiency than their Islamic counterparts which can be due to the bigger size effect of conventional banks. One interesting observation is that conventional banks suffer a big setback during crisis time and were outdone by Islamic banks.

If we focus on country specific performance as presented in figure 1(b), Saudi Arabia achieved the highest level of efficiency in both banking system whereas Bahrain performance was the worst. One plausible explanation of this result is that those countries (KSA \& Kuwait) which have high Islamic banking assets as of total banking assets and less number of Islamic banks are able to operate at better efficiency levels. This gives an insight that with lesser competition from similar type of banks yield higher efficiency level. 


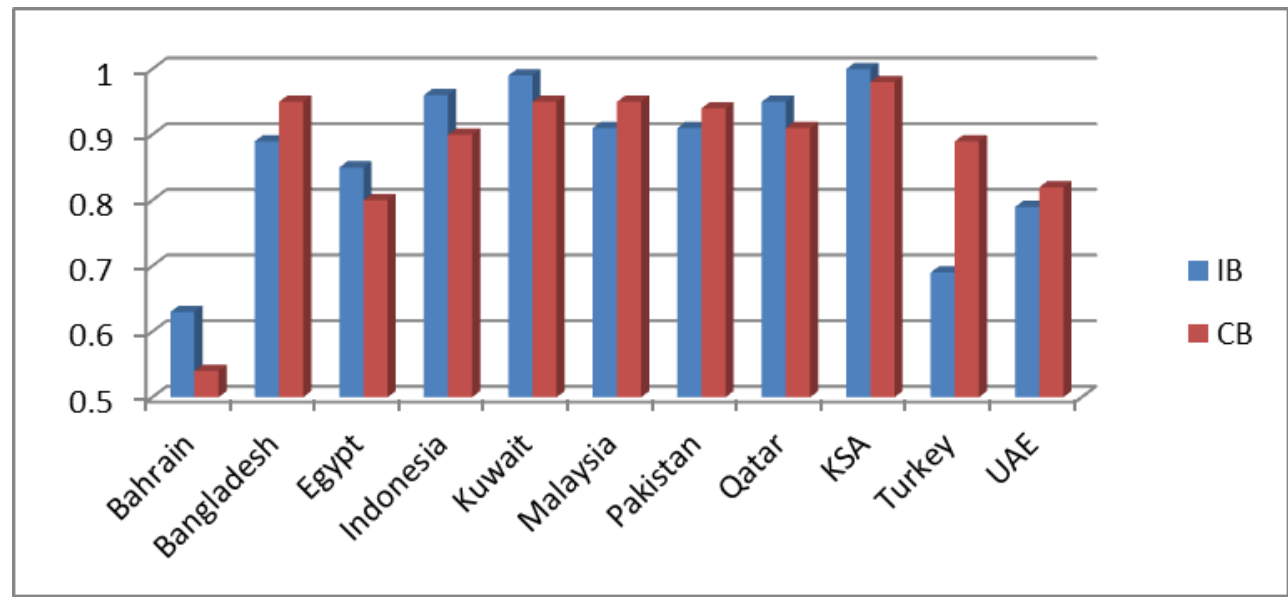

Figure 2. Technical Efficiency Scores by Country and Bank Type

The next section of analysis deals with the impact of regulatory and supervisory structures on banks' efficiency and risk taking behaviour. First we will regress DEA inefficiency scores against bank regulatory and supervisory practices in the presence of bank specific variables and then next regression will use loan loss reserve (LLR) as dependent variable with regulatory and supervisory practices as independent variables in presence of bank specific variables.

The results of regression are reported in table 2 and 3. Each table present output for overall sample, conventional bank and Islamic bank sample.

Estimates from the inefficiency equation (equation 2) derived from the simultaneous estimation are reported in Table 2. The inefficiency equation uses inefficiency estimates (INEFFij) obtained from DEA used in equation 1 as the dependent variable. The columns report the results obtained for three estimations of the system - for all banks, conventional banks and Islamic banks in our sample.

It can be observed from table 2 that SPOWER has a statistically significant and negative impact on both overall sample and Islamic banks but positive impact for conventional banks. In other words, higher supervisory power increases the technical efficiency of Islamic banks but reduces the efficiency of conventional banks. It can be due to the fact that Islamic banks apart from national banking laws are also governed by Shariah laws which are keeping in check some undesired activities of Islamic banks thus increasing their given efficiency level. Conventional bank since facing some competition from Islamic counterpart has shown decline in efficiency with strict supervisory power. Our result for Islamic banks is consistent with the findings of Pasiouras (2008) for technical efficiency. Thus, we find evidence to support the argument of the official supervision approach that powerful official supervision can improve the corporate governance of banks (Stigler, 1971). This efficiency increases further if we have some inbuilt supervisory mechanism as embedded in Islamic banking system.

CAPITRQ has a negative and statistically significant impact on inefficiency on both Islamic and conventional banks. Therefore, higher capital requirements increase the technical 
efficiency of banks. This could be explained by a number of reasons. For instance, VanHoose (2007) mention that high capital requirements may result in lower levels of bad loans thus reducing the probability of financial distress, which also increases the importance of substitutes for other potentially higher earning activities such as investment activities.

If we focus on PRMONIT variable we find negative impact on Islamic bank inefficiency and direct impact on inefficiency of conventional banks. In other words higher the level of scrutiny by regulatory body Islamic banks were able to operate at high efficiency level but not the case for conventional banks. This can be due to fact Islamic banks incorporate both high corporate governance level as well Shariah governance level which help them to reduce corruption and ambiguity in bank lending, and improve the functioning of Islamic banks as true financial intermediaries. As Fernandez and Gonzalez (2005) mention, under this combined approach of higher SPOWER and PRMONIT, a greater quality of information provided by a system that enhances private monitoring through accounting and auditing requirements might boost supervisors' abilities to intervene in managerial decisions in the right way and at the right time.

Turning to our last regulatory variable, the positive and statistically significant impact of ACTRS on technical inefficiency indicates that lower restrictions result in higher operational efficiency. This is consistent with the view that less regulatory control allows banks to engage in various activities and operate under economies of scale. In other words, our results imply that when banks are restricted in offering a limited number of services, they can potentially acquire expertise and specialization in specific market segments and be more profit efficient. The result does not differentiate by type of banks.

If we put our attention on other bank specific variables, the results for the full sample suggest that inefficient banks hold more loan loss reserves however results vary across types of banks. There appears to be positive relationship between loss reserve and efficiency for conventional banks, and an inverse relationship for Islamic banks which signify that inefficient conventional bank takes on more risk than their Islamic counterpart. This can be a useful result to prove that Islamic banks suffer fewer damages and experienced no banking failures during the recent credit crunch of 2007-2008. Further on we can observe that technical inefficiency is positively related to asset size whereas bank lending appears to be inversely related to inefficiency suggesting that efficient banks are more successful in expanding their loans business. Evidence on the relationship between bank liquidity and inefficiency is mixed. Inefficient Islamic banks maintain higher liquidity level while inefficient conventional banks maintain lower level of liquidity which makes them more prone to bank runs. Viewing the country-specific indicators, overall it seems that banking system liquidity and banking system operating cost are positively linked to inefficiency while loan loss provision is negatively related to inefficiency. However the relationship does not vary across two types of bank. In addition, $\triangle$ GDP has a positive and statistically significant effect on technical efficiency for both types of banks.

Table 2. Bank Cost Inefficiency INEFFij as Dependent Variable 


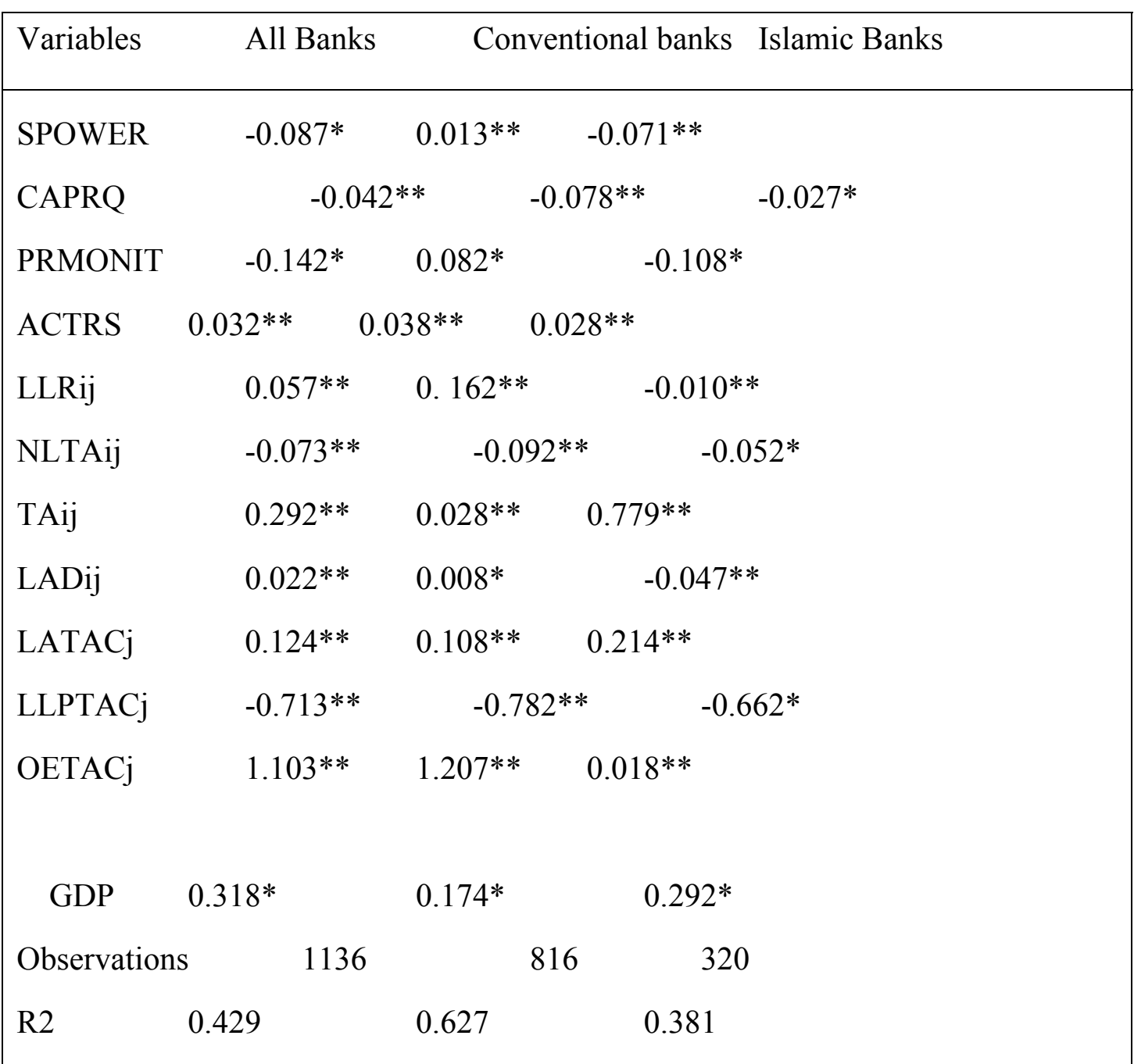

Notes: * and $* *$ indicate significance at the $5 \%$ and $1 \%$ levels, respectively.

Estimates from the risk equation (equation 3) derived from the simultaneous estimation are reported in Table 3. The risk equation uses loan-loss reserves as fraction of total asset (LLRij) as the dependent bank-risk variable. The columns report the results obtained for three estimations of the system - for all banks, conventional banks and Islamic banks in our sample.

It can be observed from Table 3 that SPOWER has negative impact on both Islamic banks and conventional banks but the relationship is not significant which is in line with Barth et.al (2004).

With respect to CAPRQ and PRMONIT we can establish statistically significant and negative relationship for both conventional banks and Islamic banks. It can be interpreted in sense that higher the capital requirement and better the monitoring and scrutiny of banking sector lower will be risk taking behaviour of these banks. It can be owing to the fact that higher capital requirements may represent entry barriers for newcomers, which would restrict competition and allow existing banks to accumulate power, resulting in a more prudent and less-risky behaviour. 
In case of ACTRS we find significant and contrasting result for conventional and Islamic banks. ACTRS has positive relationship with conventional banks which signifies that if regulators imposed restriction on banks activities conventional banks tend to embark on more risky venture. Islamic banks shows a negative relationship with ACTRS which signifies that Islamic banks takes on less risk even when their activities are restricted in the financial market. It can be explained in the sense that Islamic banks with inherent Shariah regulation and restrictions are able to avoid many risky ventures.

If we focus on bank specific variables we observe that for the full sample there is a positive relationship between inefficiency and bank risks. Banks with higher loan loss reserves tend to be inefficient. This is the case for conventional banks although it can be seen that there is an opposite relationship for Islamic banks. The positive relationship for conventional banks can be due to the fact that inefficient conventional banks take on more risk to improve their performance over the long run. The negative relationship for Islamic banks can be result of cost constraints impediment which restricts the ability of inefficient Islamic banks to take on more risks. Possibly, Islamic banks are more reserve constrained and this may be the reason behind this result. The table also shows that net lending (NLTAij) is negatively related to risk suggesting that loan growth is inseparably linked to loan loss reserve levels. Bank asset size (TAij) also seems to be important as large conventional banks appear to be more risky than their smaller Islamic counterparts and Islamic banks also seem to have a lower loan loss reserve level which is obvious since most of the Islamic loans are backed by real assets. This can be also interpreted that there are potential diversification benefits associated with size as noted by Altunbas et al. (2007).

There also appears to be a mix relationship between liquidity and risk as conventional banks with higher liquidity levels have higher reserve levels while Islamic banks have lower reserve associated with higher liquidity. This suggests that banks with higher liquidity levels take on more risks which confirm to the Basel guidelines whereby banks are encourage being more liquid to cover the risks being taken. This result also confirms that Islamic banks tend to be more liquid and less risky compared to conventional banks in the dual banking system. Finally, the country specific banking sector variables also suggest that the level of liquidity (LATACj) and loan loss provision (LLPTACj) in the respective country's financial system are positively related to overall banking sector risks. In other words banking systems will take on more risks if they are more liquid and banks are provisioning for loan loss at a higher level. There do not appear to be major differences in the relationships across conventional banks and Islamic banks. 
Table 3. Bank Risks LLRij as Dependent Variable

\begin{tabular}{|c|c|c|}
\hline Variables & All Banks & Conventional banks Islamic Banks \\
\hline SPOWER & -0.056 & $\begin{array}{ll}-0.021 & -0.054\end{array}$ \\
\hline CAPRQ - 0 & $40 * *$ & $-0.029 * * \quad-0.071 *$ \\
\hline PRMONIT & $-0.018 *$ & $-0.036^{*}-0.011^{*}$ \\
\hline ACTRS -0 & $07 * *$ & $0.041 * *-0.087 * *$ \\
\hline INEFFij $0 .($ & $99 * *$ & $0.527 * * \quad-0.016 * *$ \\
\hline NLTAij -0 & $29 * *$ & $-0.027 * *$ \\
\hline TAij & $0.054 *$ & $-0.023 * *$ \\
\hline LADij & $0.042 * *$ & $0.067 *-0.071 * *$ \\
\hline LATACj & $0.052 * *$ & $0.026 * * \quad 0.071 * *$ \\
\hline LLPTACj & $0.674 * *$ & $1.210 * *$ \\
\hline OETACj & $0.941 * *$ & $1.017 * *$ \\
\hline GDP & $0.276^{*}$ & $0 . .308^{*} \quad 0.163 *$ \\
\hline \multicolumn{2}{|c|}{ Observations $\quad 1136$} & $816 \quad 320$ \\
\hline $\mathrm{R} 2$ & & 0.394 \\
\hline
\end{tabular}

Notes: * and ** indicate significance at the $5 \%$ and $1 \%$ levels, respectively.

Nevertheless, the main findings from Table 2 and 3 prove that regulation and supervision are positively related for conventional banks' technical inefficiency and negatively related for Islamic banks' technical inefficiency. In case of impact of regulatory and supervisory practices on bank risk taking we did not find any major differences between the two types of bank.

\section{Conclusions}

This paper extends the literature on bank efficiency and risk taking by providing for the first time empirical evidence on the association between risk and efficiency with regulation and supervisory approaches in the dual banking system. Our sample consisted of a panel dataset of 1136 observations covering the period 2006-2010, from 165 conventional banks and 70 Islamic banks operating in 11 countries which have distinction of "dual-banking system". Considering the conflicting theoretical views in the literature and on-going debate on the superiority of the two alternative banking systems in form of conventional and Islamic banking system, we focused on regulations related to capital requirements, official supervisory power, market discipline, and restrictions on bank efficiency and risk taking behaviour. The efficiency scores used in our models are estimated using input-oriented DEA methodology. We also consider risk measures calculated using traditional Loan Loss Reserve ratio as requirement for Tier 2 capital.

Our results indicated that Islamic banks efficiency were positively influenced by regulations related to the second and third Pillars of Basel II, namely higher supervisory power, and disclosures while conventional banks efficiency were negatively influenced. Stricter regulations, related to the first Pillar (i.e. capital requirements) had a positive impact on technical efficiency for both groups of banks. Higher capital requirements also induce lower level of risk behaviour for both types of banks. We observed the opposite effect in the case of 
restrictions on bank activities, with higher restrictions having a negative influence on risk taking behaviour of conventional banks while reducing the level of riskiness of Islamic banks. Moreover, our findings on pillar 3 of Basel II, market discipline, indicate that excessive private monitoring and regulatory restrictions on bank activities can affect the efficient operation of banks. A message that emerges from this analysis is that there is a strong link between bank efficiency and bank regulatory and supervisory policies that obstructs private sector monitoring, bank activities. It is also conclusive that Islamic banking system works well within stricter regulatory environment compared to their conventional counterpart.

Basel II suggested that stricter regulations could hamper banking efficiency. The existence of a powerful supervisory body could also lead to inefficiency. DEA scores from this paper suggest that this may not necessarily be the case especially where a country is a developing one and does not have a proper framework to control corruption. Islamic banks appear to be efficient in difficult conditions where it does not have the traditional safeguards such as a fully function and trustworthy legal system.

The efficiency of Islamic banks where compared against its peers in the conventional side has not shown any advantages or disadvantages in regard to the system itself, many of the factors boiled down to the bank itself rather than anything else. Usually it appeared that full-fledged Islamic banks were not as efficient as those that are subsidiaries of larger conventional banks, this was definitely the case in Malaysia and the GCC region. However it does appear that issues such as capital requirements and liquidity requirements had less of an impact on Islamic banks than their conventional counterparts.

On the basis of above assertions it will not be wrong to say that Islamic banks are better equipped towards the implementation of Basel III guidelines.

Further areas of study should seek to investigate the consistency of our Dual banking findings applied to a more representative and contemporary sample of both conventional and Islamic banks. The approach could also be expanded to examine the consistency of findings by using alternative accounting and market-based indicators of banking risk, Basel capital strength factors and alternative banking efficiency measures.

\section{References}

Altunbas, Y., Carbo, S., Gardener, E.P.M., \& P. Molyneux. (2007). Examining the Relationship between Capital, Risk and Efficiency in European Banking. European Financial Management, 13(1), 49-70. http://dx.doi.org/10.1111/j.1468-036X.2006.00285.x

Altunbas, Y., Gardener, E.P.M., Molyneux, P., \& B. Moore. (2001). Efficiency in European banking. European Economic Review, 45, 1931-1955. http://dx.doi.org/10.1016/S0014-2921(00)00091-X

Andersen, P., \& N.C. Petersen. (1993). A Procedure for Ranking Efficient Units in Data Envelopment Analysis. Management Science, 39, 1261-1264. http://dx.doi.org/10.1287/mnsc.39.10.1261 
Barth, J.R., Caprio, G., \& R. Levine. (2007b). Bank Regulations are Changing: But for Better or Worse? World Bank. Retrieved from http://go.worldbank.org/SNUSW978P0.

Barth, J.R., Caprio, G., \& R. Levine. (2007a). The Microeconomic Effects of Different Approaches to Bank Supervision. In Haber, S., North, D. and B.Weingast, (Eds), The Politics of Financial Development, Stanford University Press.

Barth, J.R., Caprio, G., \& R. Levine. (2006). Rethinking Bank Regulation: Till Angels Govern. Cambridge: Cambridge University Press.

Barth, J.R., Caprio, G., \& R. Levine. (2004). Bank Regulation and Supervision: What Works Best? Journal of Financial Intermediation, 13, 205-248. http://dx.doi.org/10.1016/j.jfi.2003.06.002

Barth, J.R., Caprio, G., \& R. Levine. (2001). Banking Systems around the Globe: Do Regulations and Ownership Affect Performance and Stability? In Mishkin F.S. (ed), Prudential Supervision: What Works and What Doesn't. pp. 31-88. University of Chicago Press,

Barth, J.R., Nolle, D.E, Phumiwasana, T., \& G. Yago. (2003a). Across-Country Analysis of the Bank Supervisory Framework and Bank Performance. Financial Markets, Institutions and Instruments, 12, 67-120.

Barth, J.R., Caprio, G., \& R. Levine. (2003b). Bank Regulation and Supervision: Lessons from a New Database, In Garza J.A.M. (Ed), Macroeconomic Stability, Financial Markets, and Economic Development, Mexico City: Banco de Mexico.

Basel Committee on Bank Supervision, (2009). Strengthening the Reliance of the Banking Sector - Consultative Document. Retrieved from http://www.bis.org/publ/bcbs164.htm.

Beck, T., Demirguc-Kunt, A., \& R. Levine. (2006). Bank Supervision and Corruption in Lending. Journal of Monetary Economics, 53, 2131-2163. http://dx.doi.org/10.1016/j.jmoneco.2005.10.014

Becker, G. (1983). A Theory of Competition among Pressure Groups for Political Influence. Quarterly Journal of Economics, 98, 371-400. http://dx.doi.org/10.2307/1886017

Berger, A.N. (1995). The Profit-Structure Relationship in Banking - Tests of Market-Power and Efficiency-Structure Hypotheses. Journal of Money, Credit and Banking, 27, 404-431. http://dx.doi.org/10.2307/2077876

Berger, A.N., \& E. Bonaccorsi di Patti. (2006). Capital Structure and Firm Performance: A New Approach to Testing Agency Theory and an Application to the Banking Industry. Journal of Banking and Finance, 30, 1065-1102. http://dx.doi.org/10.1016/j.jbankfin.2005.05.015

Berger, A.N., \& T. Hannan. (1998). The Efficiency Cost of Market Power in the Banking Industry: A Test of the 'Quiet life' and Related Hypotheses. Review of Economics and Statistics, 80, 454-465. http://dx.doi.org/10.1162/003465398557555 
Berger, A.N., Herring R.J., \& G.P. Szego. (1995). The Role of Capital in Financial Institutions. Journal of Banking and Finance, 19, 393-430. http://dx.doi.org/10.1016/0378-4266(95)00002-X

Berger, A.N., \& D.B. Humphrey. (1997). Efficiency of Financial Institutions: International Survey and Directions for Further Research. European Journal of Operational Research, 98, 175-212. http://dx.doi.org/10.1016/S0377-2217(96)00342-6

Berger, A.N., Hunter, W.C., \& S.G Timme. (1993). The efficiency of financial institutions: A review and preview of past, present and future. Journal of Banking and Finance, 17, 221-249. http://dx.doi.org/10.1016/0378-4266(93)90030-H

Berger, A.N., Klapper, L.F., \& R. Turk-Ariss. (2008). Banking Structures and Financial Stability. Mimeo. http://dx.doi.org/10.1596/1813-9450-4696

Berger, A.N., \&L.J. Mester. (1997). Inside the Black Box: What Explains Differences in the Efficiencies of Financial Institutions? Journal of Banking and Finance, 21, 895-947. http://dx.doi.org/10.1016/S0378-4266(97)00010-1

Blum, J. (1999). Do Bank Capital Adequacy Requirements Reduce Risks. Journal of Banking and Finance, 23, 755-771. http://dx.doi.org/10.1016/S0378-4266(98)00113-7

Brunnermeier, M., \& L. Pedersen. (2009). Market Liquidity and Funding Liquidity. Review of Financial Studies 22, 2201-2238. http://dx.doi.org/10.1093/rfs/hhn098

Calem, P., \& R. Rob. (1999). The Impact of Capital-Based Regulation on Bank Risk-Taking. Journal of Financial Intermediation, 8, 317-352. http://dx.doi.org/10.1006/jfin.1999.0276

Casu, B., \& C. Girardone. (2006). Bank Competition, Concentration and Efficiency in the Single European Market. The Manchester School, 74, 441-468. http://dx.doi.org/10.1111/j.1467-9957.2006.00503.x

Casu, B., \& P. Molyneux. (2003). A Comparative Study of Efficiency in European Banking. Applied Economics, 35, 1865-1876. http://dx.doi.org/10.1080/0003684032000158109

Cazals, C., Florence, J.P., \& L. Simar. (2002). Non Parametric Frontier Estimation: A Robust $\begin{array}{lllll}\text { Approach. Journal of } & \text { Econometrics, } & 106, & 1-25 .\end{array}$ http://dx.doi.org/10.1016/S0304-4076(01)00080-X

Delis, M.D. \& Molyneux, P., \& Pasiouras, F. (2009). Regulations and productivity growth in banking, MPRA Paper 13891, University Library of Munich, Germany.

Demirguc-Kunt, A., Detragiache, E., \& T. Tressel. (2008). Banking on the Principles: Compliance with Basel Core Principles and Bank Soundness. Journal of Financial Intermediation, 17, 511-542. http://dx.doi.org/10.1016/j.jfi.2007.10.003

Demirguc-Kunt, A., Laeven, L., \& R. Levine. (2004). Regulations, Market Structure, Institutions, and the Cost of Financial Intermediation. Journal of Money, Credit and Banking, 36, 593-622. http://dx.doi.org/10.1353/mcb.2004.0045 
Demirguc-Kunt, A., \& V. Maksimovic. (1998). Law, Finance and Firm Growth. Journal of Finance, 53, 2107-2137. http://dx.doi.org/10.1111/0022-1082.00084

Dietsch, M. and A. Lozano-Vivas, (2000). How the Environment Determines Banking Efficiency: A Comparison Between French and Spanish Industries. Journal of Banking and Finance, 24, 985-1004. http://dx.doi.org/10.1016/S0378-4266(99)00115-6

Fernandez, A.I., \& F. Gonzalez. (2005). How Accounting and Auditing Systems Can Counteract Risk-Shifting of Safety-Nets in Banking: Some International Evidence. Journal of Financial Stability, 1, 466-500. http://dx.doi.org/10.1016/j.jfs.2005.07.001

Flannery, M.J., S.H. Kwan, \& M. Nimalendran. (2004). Market Evidence on the Opaqueness of Banking Firms' Assets. Journal of Financial Economics, 71, 419-460. http://dx.doi.org/10.1016/S0304-405X(03)00185-5

Fries, S., \& A. Taci. (2005). Cost efficiency of banks in transition: Evidence from 289 banks in 15 post-communist countries. Journal of Banking and Finance, 29, 55-81. http://dx.doi.org/10.1016/j.jbankfin.2004.06.016

Goddard, J.A., Molyneux, P., \& J.O.S. Wilson. (2001). European Banking: Efficiency, Technology, and Growth. Chichester, John Wiley.

Gorton, G. and A. Winton, (1995). Bank Capital Regulation in General Equilibrium. Wharton Financial Institutions Centre, Working Paper.

Grigorian, D., \& V. Manole. (2006). Determinants of commercial bank performance in transition: An application of Data Envelopment Analysis. Comparative Economic Studies 48, 497-522. http://dx.doi.org/10.1057/palgrave.ces.8100129

Herring, R. (2005). Implementing Basel II: Is the Game Worth the Candle? Financial Markets, Institutions and Instruments, 267-287. http://dx.doi.org/10.1111/j.0963-8008.2005.00108.x

Hovakimian, A, \& E.J. Kane, (2000). Effectiveness of capital regulation at U.S. commercial banks, 1985 to 1994 . Journal of Finance, 55, 451-468. http://dx.doi.org/10.1111/0022-1082.00212

Hughes, J.P., Mester, L., \& C. Moon. (2001). Are Scale Economies in Banking Elusive or Illusive. Evidence Obtained by Incorporating Capital Structure and Risk-Taking into models of Bank Production. Journal of Banking and Finance, 25, 2169-2208. http://dx.doi.org/10.1016/S0378-4266(01)00190-X

Jeon, Y., \& S.M. Miller. (2001). Deregulation and Structural Change in the US Commercial Banking Industry. University of Connecticut, Department of Economics, Working Papers, No. 7.

Kaufmann, D., Kraay, A., \& M. Mastruzzi. (2009). Governance Matters VIII: Aggregate and Individual Governance Indicators, 1996-2008. The World Bank, Policy Research Working Paper, No. 4978. 
Kwan, S., \& R. Eisenbeis. (1997). Bank Risk, Capitalization and Operating Efficiency. Journal of Financial Services Research, 12, 117-131. http://dx.doi.org/10.1023/A:1007970618648

Laeven, L., \& Levine, R. (2007). Is There a Diversification Discount in Financial Conglomerates? Journal of Financial Economics, Vol. 85 331-67. http://dx.doi.org/10.1016/j.jfineco.2005.06.001

Lang, G., \& P. Welzel. (1998). Technology and cost efficiency in universal banking: A "Thick Frontier"analysis of the German banking industry. Journal of Productivity Analysis, 10, 63-84. http://dx.doi.org/10.1023/A:1018346332447

Lozano-Vivas, A., Pastor, J.T., \& J.M. Pastor. (2002). An Efficiency Comparison of European Banking Systems Operating Under Different Environmental Conditions. Journal of Productivity Analysis, 18, 59-77. http://dx.doi.org/10.1023/A:1015704510270

McDonald, J. (2009). Using Least Squares and Tobit in Second Stage DEA Efficiency Analyses. European Journal of Operational Research, 197, 792-798. http://dx.doi.org/10.1016/j.ejor.2008.07.039

Mester, L.J. (1996). A study of Bank Efficiency taking into account Risk- Preferences. Journal of Banking and Finance, 20, 1025-1045. http://dx.doi.org/10.1016/0378-4266(95)00047-X

Molyneux, P. (2003). Regulation and Financial Innovation Trends in European Banking and the Impact on the Supply and Demand for Financial Services in Europe. United Nations University, Institute for New Technologies, EIFC - Technology and Finance, Working Papers, No. 16.

Ng, Jeffrey and S. Roychowdhury, (2011). Do Loan Loss Reserves Behave like Capital? Evidence from Recent Bank Failures. Retrieved from http://ssrn.com/abstract=1646928

Papke, L.E., \& J.M. Wooldridge. (1996). Econometric Methods for Fractional Response Variables with an Application to 401(K) Plan Participation Rates. Journal of Applied Econometrics, 11 , 619-632. http://dx.doi.org/10.1002/(SICI)1099-1255(199611)11:6<619::AID-JAE418>3.0.CO;2-1

Pasiouras, F., Tanna, S., \& C. Zopounidis. (2009). The Impact of Banking Regulations on Banks' Cost and Profit Efficiency: Cross-Country Evidence. International Review of Financial Analysis, 18, 294-302. http://dx.doi.org/10.1016/j.irfa.2009.07.003

Pasiouras, F. (2008). International Evidence on the Impact of Regulations and Supervision on Banks' Technical Efficiency: An Application of two-stage Data Envelopment Analysis. Review of Quantitative Finance and Accounting, 30, 187-223. http://dx.doi.org/10.1007/s11156-007-0046-7

Pasiouras, F., Gaganis, C., \& C. Zopounidis. (2006). The Impact of Bank Regulations, Supervision, Market Structure, and Bank Characteristics on Individual Bank Ratings: A 
Cross-Country Analysis. Review of Quantitative Finance and Accounting, 27, 403-438. http://dx.doi.org/10.1007/s11156-006-0045-0

Ramalho, E.A., J.J.S. Ramalho, \& P.D. Henriques. (2010). Fractional regression models for second stage DEA efficiency analyses. Journal of Productivity Analysis, 34, 239-255. http://dx.doi.org/10.1007/s11123-010-0184-0

Rehman, S., \& Perry, F. (2011). Globalization Of Islamic Finance: Myth Or Reality? International Journal of Humanities and Social Science, 1,107-119 .

Reinhart, C., \& K. Rogoff. (2008). This Time is Different: A Panomaric View of Eight Centuries of Financial Crises. NBER, Working Paper 13882.

Rochet, J. (1992). Capital Requirements and the Behaviour of Commercial Banks. European Economic Review, 36, 1137-1170. http://dx.doi.org/10.1016/0014-2921(92)90051-W

Schaeck, K., Cihak, M., \& S. Wolfe. (2009). Are Competitive Banking Systems More Stable? Journal of Money, Credit and Banking, 41, 711-734. http://dx.doi.org/10.1111/j.1538-4616.2009.00228.x

Schure, P., Wagenvoort, R., \& D. O' Brien. (2004). The Efficiency and the Conduct of European Banks: Developments after 1992. Review of Financial Economics, 13, 371-396. http://dx.doi.org/10.1016/j.rfe.2004.01.001

Sealey, C.W. and J.T. Lindley. (1977). Inputs, Outputs and Theory of Production and Costs at Depository Financial Institutions. Journal of Finance, 34, 1251-1266. http://dx.doi.org/10.2307/2326527

Simar, L., \& P.W. Wilson. (2007). Estimation and Inference in two-stage, semiparametric models of production processes. Journal of Econometrics, 136, 31-64. http://dx.doi.org/10.1016/j.jeconom.2005.07.009

Spong, Kenneth. (2000). Banking Regulation: Its Purposes, Implementation, and Effects. Federal Reserve Bank of Kansas City, Kansas City: MO.

Stavarek, D. (2004). Banking efficiency in Visegrad countries before joining the European Union. European Review of Economics and Finance, 3, 129-167.

Stiglitz, J.E. (1994). The Role of the Statein Financial Markets. Proceedings of the World Bank Annual Conference on Development Economics, The World Bank, 19-52.

VanHoose, D. (2007). Theories of Bank Behaviour under Capital Regulation. Journal of Banking and Finance, 31, 3680-3697. http://dx.doi.org/10.1016/j.jbankfin.2007.01.015

Yildirim, H.S., \& G.C. Philippatos, (2007). Efficiency of Banks: Recent Evidence from the Transition Economies of Europe (1993-2000). European Journal of Finance,13, 123-143. http://dx.doi.org/10.1080/13518470600763687 
Appendix 1. Information on Regulatory, Bank Specific \& Country Specific Variables

\begin{tabular}{|c|c|c|c|}
\hline Variable & Category & Description & Source/Database \\
\hline \multicolumn{4}{|c|}{ Regulatory variables } \\
\hline SPOWER & $\begin{array}{l}\text { Supervisory } \\
\text { Power }\end{array}$ & $\begin{array}{l}\text { This variable is determined by adding } 1 \text { if the answer is yes } \\
\text { and } 0 \text { otherwise, for each one of the following fourteen } \\
\text { questions: (1) Does the supervisory agency have the right } \\
\text { to meet with external auditors to discuss their report } \\
\text { without the approval of the bank? (2) Are auditors required } \\
\text { by law to communicate directly to the supervisory agency } \\
\text { any presumed involvement of bank directors or senior } \\
\text { managers in illicit activities, fraud, or insider abuse? (3) } \\
\text { Can supervisors take legal action against external auditors } \\
\text { for negligence? (4) Can the supervisory authorities force a } \\
\text { bank to change its internal organizational structure? (5) Are } \\
\text { off-balance sheet items disclosed to supervisors? (6) Can } \\
\text { the supervisory agency order the bank's directors or } \\
\text { management to constitute provisions to cover actual or } \\
\text { potential losses? (7) Can the supervisory agency suspend } \\
\text { director's decision to distribute dividends? (8) Can the } \\
\text { supervisory agency suspend director's decision to distribute } \\
\text { bonuses? (9) Can the supervisory agency suspend } \\
\text { director's decision to distribute management fees? (10) Can } \\
\text { the supervisory agency supersede bank shareholder rights } \\
\text { and declare bank insolvent? (11) Does banking law allow } \\
\text { supervisory agency or any other government agency (other } \\
\text { than court) to suspend some or all ownership rights of a } \\
\text { problem bank? (12) Regarding bank restructuring and } \\
\text { reorganization, can the supervisory agency or any other } \\
\text { government agency (other than court) supersede } \\
\text { shareholder rights? (13) Regarding bank restructuring \& } \\
\text { reorganization, can supervisory agency or any other } \\
\text { government agency (other than court) remove and replace } \\
\text { management? (14) Regarding bank restructuring \& } \\
\text { goorganization, can supervisory agency or any other }\end{array}$ & $\begin{array}{l}\text { WB (Barth et al., } \\
\text { 2001, 2004, 2006) }\end{array}$ \\
\hline CAPRQ & $\begin{array}{l}\text { Capital } \\
\text { requirements }\end{array}$ & $\begin{array}{l}\text { This variable is determined by adding } 1 \text { if the answer is yes } \\
\text { to questions } 1-6 \text { and } 0 \text { otherwise, while the opposite occurs } \\
\text { in the case of questions } 7 \text { and } 8 \text { (i.e. yes }=0 \text {, no }=1 \text { ). (1) Is } \\
\text { the minimum required capital asset ratio risk-weighted in } \\
\text { line with Basle guidelines? (2) Does the ratio vary with } \\
\text { market risk? (3-5) Before minimum capital adequacy is } \\
\text { determined, which of the following are deducted from the }\end{array}$ & $\begin{array}{l}\text { WB (Barth et al., } \\
2001,2004,2006)\end{array}$ \\
\hline
\end{tabular}




\begin{tabular}{|c|c|c|c|}
\hline & & $\begin{array}{l}\text { book value of capital: (a) market value of loan losses not } \\
\text { realized in accounting books? (b) unrealized losses in } \\
\text { securities portfolios? (c) unrealized foreign exchange } \\
\text { losses? (6) Are the sources of funds to be used as capital } \\
\text { verified by the regulatory/supervisory authorities? (7) Can } \\
\text { the initial or subsequent injections of capital be done with } \\
\text { assets other than cash or government securities? (8) Can } \\
\text { initial disbursement of capital be done with borrowed } \\
\text { funds? }\end{array}$ & \\
\hline PRMONIT & $\begin{array}{l}\text { Private } \\
\text { Monitoring }\end{array}$ & $\begin{array}{l}\text { This variable is determined by adding } 1 \text { if the answer is yes } \\
\text { to questions } 1-6 \text { and } 0 \text { otherwise, while the opposite occurs } \\
\text { in the case of questions } 7 \text { and } 8 \text { (i.e. yes=0, no =1). (1) Is } \\
\text { subordinated debt allowable (or required) as part of capital? } \\
\text { (2) Are financial institutions required to produce } \\
\text { consolidated accounts covering all bank and any non-bank } \\
\text { financial subsidiaries? (3) Are off-balance sheet items } \\
\text { disclosed to public? (4) Must banks disclose their risk } \\
\text { management procedures to public? (5) Are directors legally } \\
\text { liable for erroneous/misleading information? (6) Do } \\
\text { regulations require credit ratings for commercial banks? (7) } \\
\text { Does accrued, though unpaid interest/principal enter the } \\
\text { income statement while loan is non-performing? (8) Is } \\
\text { there an explicit deposit insurance protection system? }\end{array}$ & $\begin{array}{l}\text { WB (Barth et al., } \\
\text { 2001, 2004, 2006) }\end{array}$ \\
\hline ACTRS & $\begin{array}{l}\text { Restrictions } \\
\text { on } \\
\text { Banks } \\
\text { Activities }\end{array}$ & 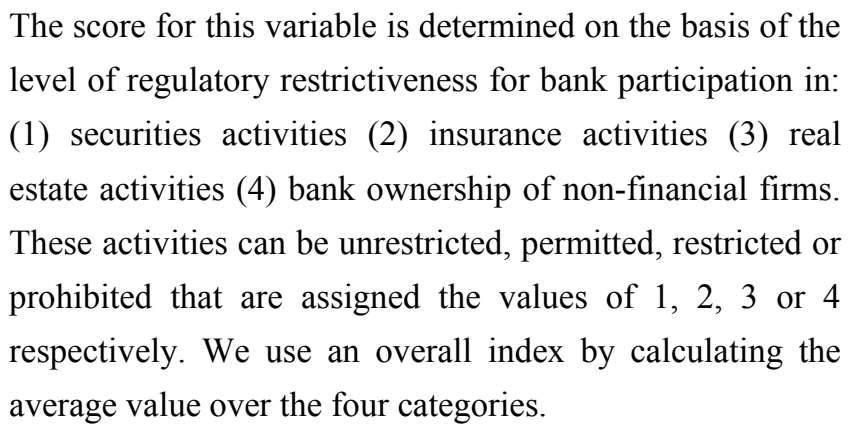 & $\begin{array}{l}\text { WB (Barth et al., } \\
\text { 2001, 2004, 2006) }\end{array}$ \\
\hline \multicolumn{4}{|c|}{ Bank Specific Variables } \\
\hline $\mathrm{INEFF}_{\mathrm{ij}}$ & \multicolumn{2}{|c|}{ Technical Inefficiency for bank $\mathrm{i}$ in country $\mathrm{j}$} & $\begin{array}{l}\text { DEA Analysis and } \\
\text { Author calculation }\end{array}$ \\
\hline LLRij & \multicolumn{2}{|c|}{ Loan-loss reserves for bank $\mathrm{i}$ in country $\mathrm{j}$} & $\begin{array}{l}\text { Bankscope and } \\
\text { Author calculation }\end{array}$ \\
\hline NLTAij & \multicolumn{2}{|c|}{ Net loans to total assets for bank $i$ in country $j$} & $\begin{array}{l}\text { Bankscope and } \\
\text { Author calculation }\end{array}$ \\
\hline TAij & \multicolumn{2}{|c|}{ total assets for bank $\mathrm{i}$ in country $\mathrm{j}$} & $\begin{array}{l}\text { Bankscope and } \\
\text { Author calculation }\end{array}$ \\
\hline LADij & \multicolumn{2}{|c|}{ Liquid asset to short term deposit for bank $\mathrm{i}$ in country $\mathrm{j}$} & $\begin{array}{l}\text { Bankscope and } \\
\text { Author calculation }\end{array}$ \\
\hline
\end{tabular}




\begin{tabular}{|c|c|c|}
\hline Year $_{j}$ & Yearly dummy variables for 2006 to 2010 & Author \\
\hline \multicolumn{3}{|c|}{ Country Specific Variables } \\
\hline LATACj & Banking system liquid assets to total assets in country $\mathrm{j}$ & $\begin{array}{l}\text { Bankscope and } \\
\text { Author calculation }\end{array}$ \\
\hline OETACj & Banking system operating expenses to total assets in country $j$ & $\begin{array}{l}\text { Bankscope and } \\
\text { Author calculation }\end{array}$ \\
\hline LLPTACj & Banking system loan-loss provisions to total loans in country $j$ & $\begin{array}{l}\text { Bankscope and } \\
\text { Author calculation }\end{array}$ \\
\hline$\Delta \mathrm{GDP}$ & Real GDP Growth & IMF \\
\hline
\end{tabular}

